\title{
Assessment of Active Learning Modules: An Update of Research Findings
}

\section{Dr. Ashland O. Brown, University of the Pacific}

Dr. Ashland O. Brown is currently a professor of Mechanical Engineering at the University of the Pacific's School of Engineering and Computer Science. He served as a program director in the Mechanical/Civil Engineering section of the National Science Foundation from 1998 to 1999. He served as dean of engineering at the University of the Pacific from 1991 to 1998, and dean of engineering technology at South Carolina State University from 1989 to 1991 . He served as an engineering group manager for Body Structures Design Group at General Motor Corporation in the Warren Technical Center from 1984 to 1989. Dr, Brown was also an engineering principal engineer for a number of engine, and structural design groups at Ford Motor Company from 1977 to 1984. He was a research engineer at Eastman Kodak Corporation from 1974 to 1977. Dr. Brown received both his M.S. and his Ph.D. in Mechanical Engineering from the University of Connecticut at Storrs, CT in 1970 and 1974 respectively. He earned his B.S. in Mechanical Engineering from Purdue University at West Lafayette, Ind. in 1966. He is currently the PI at the University of the Pacific for the four-year collaborative National Science Foundation TUES DUE grant entitled Improving Learning for Undergraduate Engineering Programs using Finite Element Learning Modules. This is a joint collaboration award with the University of Texas, in Austin. He has authored approximately 50 papers with over 20 using finite element learning modules in undergraduate engineering. $\mathrm{He}$ was the PI for the initial four year, NSF CCI grant entitled The Finite Element Method Exercises for Use in Undergraduate Engineering Programs.

\section{Dr. Richard H. Crawford, University of Texas, Austin}

Dr. Richard H. Crawford is a professor of Mechanical Engineering at the University of Texas at Austin and is the Temple Foundation Endowed Faculty Fellow No. 3. He is also Director of the Design Projects program in Mechanical Engineering. He received his B.S. in Mechanical Engineering from Louisiana State University in 1982, and his M.S. in Mechanical Engineering in 1985 and his Ph.D. in 1989, both from Purdue University. He teaches mechanical engineering design and geometry modeling for design. Dr. Crawford's research interests span topics in computer-aided mechanical design and design theory and methodology. Dr. Crawford is co-founder of the DTEACh program, a "Design Technology" program for $\mathrm{K}-12$, and is active on the faculty of the UTeachEngineering program that seeks to educate teachers of high school engineering.

\section{Dr. Daniel D. Jensen, U.S. Air Force Academy}

Dr. Dan Jensen is a professor of engineering mechanics at the U.S. Air Force Academy where he has been since 1997. He received his B.S. in Mechanical Engineering, his M.S. in Applied Mechanics and his Ph.D. in Aerospace Engineering Science from the University of Colorado at Boulder. He has worked for Texas Instruments, Lockheed Martin, NASA, University of the Pacific, Lawrence Berkeley National Lab and MSC Software Corp. His research includes design of Micro Air Vehicles, development of innovative design methodologies and enhancement of engineering education. Dr Jensen has authored approximately 100 papers and has been awarded over $\$ 3$ million of research grants.

\section{Dr. Joseph J. Rencis P.E., Tennessee Technological University}

Dr. Joseph J. Rencis is the dean of engineering by the Clay N. Hixson Chair for Engineering Leadership, and professor of mechanical engineering at Tennessee Technological University. From 2004 to 2011, he was in the Department of Mechanical Engineering at the University of Arkansas, Fayetteville and was Department Head, inaugural 21st Century Leadership Chair in Mechanical Engineering, and professor. From 1985 to 2004, he was professor and director of Engineering Mechanics in the Mechanical Engineering Department at Worcester Polytechnic Institute. His research focuses on boundary element methods, finite element methods, atomistic modeling, and engineering education. He currently serves on the editorial board of Engineering Analysis with Boundary Elements and the Journal of Online Engineering 
Education. He is an associate editor of the International Series on Advances in Boundary Elements. Currently, he serves as chair of ASEE Professional Interest Council (PIC) III, an ABET program evaluator, and a member of the ASME National Nominating Committee. He received the 2002 ASEE New England Section Teacher of Year Award, the 2004 ASEE New England Section Outstanding Leader Award, the 2006 ASEE Mechanics Division James L. Meriam Service Award, and the 2010 ASEE Midwest Section Outstanding Service Award. Rencis is a fellow of ASEE and ASME. He received a B.S. from Milwaukee School of Engineering in 1980, a M.S. from Northwestern University in 1982, and a Ph.D. from Case Western Reserve University in 1985.

\section{Prof. Jiancheng Liu, University of the Pacific}

Dr. Jiancheng Liu is an associate professor of the Department of Mechanical Engineering at the University of the Pacific. Prior to joining at the University of the Pacific, he has worked in industries for many years. His research focuses on CNC machine design and analysis, computer-aided manufacturing and manufacturing system automation. He has published more than 80 peer reviewed technical journal and conference papers. Dr. Liu was also awarded four patents. He has invented many new technologies which have been practically applied in industries. He received the Industrial LEAD Award from SME in 2001. Dr. Liu received his B.S. and M.S. degrees in mechanical engineering in China. After receiving his Ph.D. degree in Japan, he moved to the United States in 1997 and did his post-doctorate work at the University of California,

\section{Prof. Kyle A. Watson, University of the Pacific}

Dr. Kyle A. Watson is an associate professor of Mechanical Engineering at the University of the Pacific. He has taught undergraduate courses in thermodynamics, heat transfer, combustion, air-conditioning, dynamics, capstone design, and introduction to engineering. Dr. Watson received his B.S. in Mechanical Engineering from Villanova University and his M.S. and Ph.D. in Mechanical Engineering from North Carolina State University. He has published numerous journal articles in the areas of experimental combustion science and engineering pedagogy.

\section{Dr. Kathy Schmidt Jackson, Pennsylvania State University, University Park}

Dr. Kathy Jackson is a senior research associate at Pennsylvania State University's Schreyer Institute for Teaching Excellence. In this position, she promotes Penn State's commitment to enriching teaching and learning. Dr. Jackson works in all aspects of education including faculty development, instructional design, engineering education, learner support, and evaluation.

\section{Prof. Rachelle Kisst Hackett, University of the Pacific}

Dr. Rachelle Hackett is an associate professor in the Educational and School Psychology Department in the Benerd School of Education where she teaches graduate students social science research methodology and applied statistics. She also serves as an independent evaluator of various educational programs designed to improve STEM teaching and learning.

\section{Prof. Paul Henry Schimpf, Eastern Washington University}

Dr. Paul H. Schimpf received his B.S. in Electrical Engineering (Summa Cum Laude), his M.S. in Electrical Engineering, and his Ph.D. from the University of Washington at Seattle in 1982, 1987, and 1995, respectively. He began his academic career in 1998, and is currently the chair of the Department of Computer Science at Eastern Washington University in Cheney, Wash. His research interest includes numerical methods for forward and inverse solutions to partial differential equations with biomedical applications. Prior to his academic career, he was employed as a senior principal design engineer in the electronics industry, where he enjoyed fifteen years of experience developing parallel embedded signal and image processing systems. 


\section{Dr. Chuan-Chiang Chen, California State Polytechnic University, Pomona}

Dr. Chen has been an associate professor in the Mechanical Engineering department at California State Polytechnic University Pomona since 2009. He earned his B.S. from National ChiaoTung University in Taiwan and his M.S. and Ph.D. from Ohio State University. All are in the field of Mechanical Engineering. Prior to joining Cal Poly Pomona, he was an assistant professor in the Mechanical Engineering Department at Tuskegee University. His teaching and research interests include solid mechanics, system dynamics, measurements, noise and vibrations.

\section{Dr. Ismail I Orabi, University of New Haven}

Dr. Orabi joined the faculty of the Mechanical Engineering department at the University of New Haven in 1986. Dr. Orabi received his B.S. in Mechanical Engineering from Cairo Institute of Technology (now Helwan University), in 1975, his M.S. degree in Mechanical Engineering from the State University of New York at Buffalo, in 1982, and his Ph.D. degree from Clarkson University, in 1987. Prior to joining the University of New Haven, he taught at Clarkson University as an Instructor for two years in the department of mechanical engineering and two years at the Cairo Institute of Technology. Dr. Orabi has received a number of research awards from the state of Connecticut, Untied Technologies, and NSF. In 2010, he was awarded an NSF-grant proposal in collaboration with eight colleges to Improved Learning for Undergraduate Engineering Programs for $\$ 600,000$. He has established two laboratories: the Materials Testing Laboratory sponsored by the National Science Foundation, and the Engineering Multimedia Laboratory funded by AT\&T. Dr. Orabi was awarded the ASEE Instrumentation Division Best Paper Award in 2000. He was a visiting professor at Rensselaer Polytechnic Institute (RPI) from 1996 to 1998. He is a member of ASME and ASEE.

\section{Dr. Firas Akasheh, Tuskegee University \\ Dr. John J Wood, U.S. Air Force Academy}

Dr. John J. Wood is currently an associate professor of Engineering Mechanics at the United States Air Force Academy. Dr. Wood completed his Ph.D. in Mechanical Engineering at Colorado State University in the design and empirical analysis of compliant systems. He received his M.S. in Mechanical Engineering at Wright State University and his B.S. in Aeronautical Engineering from Embry-Riddle Aeronautical University in 1984. Dr. Wood joined the faculty at the United States Air Force Academy in 1994 while serving on active duty in the U.S. Air Force. After completing his Ph.D. in 2002, he returned to the Air Force Academy where he has been on the faculty since. The current focus of Dr. Wood's research includes the development of robotic ground and air vehicle systems using innovative design techniques using current technology implementations, as well as futuristic projections. Dr Wood also publishes research on advances in the methodology for creative electromechanical systems design.

\section{Brock U Dunlap, University of Texas, Austin}

Brock Dunlap is currently a graduate student at the University of Texas at Austin studying active learning and prototyping methodology. He plans to graduate in May 2014 with a master's degree in Mechanical Engineering with a focus in design and manufacturing. He holds a bachelor's degree in Mechanical Engineering from Brigham Young University.

\section{Ella R. Sargent, University of the Pacific}

Ella Sargent is currently a graduate research assistant and school psychology doctoral student in the Benerd School of Education at the University of the Pacific. She received her B.A. in Psychology from California State University, Long Beach. 


\title{
Assessment of Finite Element Active Learning Modules: An Update in Research Findings
}

\begin{abstract}
The landscape of contemporary engineering education is ever changing, adapting and evolving. As an example, finite element theory and application has often been included in graduate-level courses in engineering programs; however, current industry needs bachelor's-level engineering graduates with skills in applying this essential analysis and design technique. Engineering education is also changing to include more active learning. In response to the need to introduce undergrads to the finite element method as well as the need for engineering curricula to include more active learning, we have developed, implemented and assessed a suite of Active Learning Module (ALMs).The ALMs are designed to improve student learning of difficult engineering concepts while students gain essential knowledge of finite element analysis. We have used the Kolb Learning Cycle as a conceptual framework to guide our design of the ALMs.

Originally developed using MSC Nastran, followed by development efforts in SolidWorks Simulation, ANSOFT, ANSYS, and other commercial FEA software packages, a team of researchers, with National Science Foundation support, have created over twenty-eight active learning modules. We will discuss the implementation of these learning modules which have been incorporated into undergraduate courses that cover topics such as machine design, mechanical vibrations, heat transfer, bioelectrical engineering, electromagnetic field analysis, structural fatigue analysis, computational fluid dynamics, rocket design, chip formation during manufacturing, and large scale deformation in machining.

This update on research findings includes statistical results for each module which compare performance on pre- and post-learning module quizzes to gauge change in student knowledge related to the difficult engineering concepts that each module addresses. Statistically significant student performance gains provide evidence of module effectiveness. In addition, we present statistical comparisons between different personality types (based on Myers-Briggs Type Indicator, MBTI, subgroups) and different learning styles (based on Felder-Solomon ILS subgroups) in regards to the average gains each group of students have made on quiz performance. Although exploratory, and generally based on small sample sizes at this point in our multi-year effort, the modules for which subgroup differences are found are being carefully reviewed in an attempt to determine whether modifications should be made to better ensure equitable impact of the modules across students from specific personality and / or learning styles subgroups (e.g., MBTI Intuitive versus Sensing; ILS Sequential versus Global).
\end{abstract}




\section{Introduction}

As educators advance engineering education, active learning tools are becoming preferred choices for addressing how students struggles with complex topics in engineering, especially as a function of their backgrounds, demographics, and personality type. In order to move beyond the typical road bumps encountered when teaching difficult concepts, contemporary methods are being developed that seek to engage students actively, both inside and outside the classroom, as well as kinesthetically through the various human senses. Such approaches have the potential to improve student comprehension and knowledge retention, and most importantly, to increase students' interest in the material. [1]

Assisting students in the learning of imperative analysis tools is especially important with current advanced techniques used in industry. One such technique is finite element analysis. The finite element (FE) method is widely used to analyze engineering problems in many commercial engineering firms. It is an essential and powerful analytical tool used to design products with ever shorter development cycles. [2-4]. Today this tool is primarily taught at the graduate engineering level due to the fact that FE theory is very mathematics-intensive which in the past has made it more suitable for graduate engineering students who have a more rigorous mathematical education. This has changed most recently with the advent of high speed inexpensive computers and workstations and fast algorithms which simplify the FE software. Introducing new material into the already packed 4 year engineering programs poses challenges to most instructors. The need for integrating FE theory and application across the engineering curriculum has been established and methods have been suggested by other engineering authors [4-6]. This paper discusses the technique of designing finite element active learning modules (ALM) across many areas of engineering and the success of these modules in improving the student's understanding of the engineering concepts and of the finite element analysis technique. Previous authors over the past six years have reported their success in using their finite element learning modules. [7-15]

The primary focus of this paper is to report the incremental student improvement in engineering learning from using many of the twenty-eight FE learning modules in nine specific areas of engineering at nine engineering colleges and universities over the past six years. This paper is an update of the research reported in an earlier paper. This paper also reports the initial findings on the effects of student personality types on improvement in specific engineering areas of these ALMs.

An important goal for this work is to educate a diverse undergraduate group of engineering students with the basic knowledge of FE theory, along with practical experience in applying commercial FE software to engineering problems. The lack of experience in using numerical computational methods in designing solutions to structural, vibrational, electromagnetic, biomedical electromagnetics, computational fluid dynamics, and heat transfer is a noted problem for some engineering graduates [16-17]. The Accreditation Board for Engineering and 
Technology, Inc. (ABET, Inc.) expects engineering graduates to have "an ability to use the techniques, skills, and modern engineering tools necessary for engineering practice"[18] such as FE analysis. Hence, engineering schools have, or are planning to add FE analysis to their curricula [19-25], but these plans are not occurring fast enough to meet the demand of firms competing in the global economy.

All learning modules developed in these six years of work are available free to all USA engineering educational institutions on http://sites.google.com/site/finiteelementlearning/home.

Initially, we developed FE learning modules in six engineering areas: (1) structural analysis, (2) mechanical vibrations, (3) computational fluid dynamics, (4) heat transfer, (5) electromagnetics, and (6) biometrics. To evaluate these "Proof of Concept" modules, they were integrated into existing courses in the corresponding subject areas. Faculty and students initially assessed their effectiveness at three higher educational institutions. We included student demographic data, learning style preference data and MBTI data in the surveys' conducted on these initial twelve learning modules, but found that the sample size was in most instances too small to develop any statistically meaningful analysis.

In the second Phase 2 work we expanded our FE learning modules to an additional three engineering areas: (7) fatigue analysis, (8) manufacturing process analysis and (9) manufacturing forming analysis. We continued to integrate these learning modules into existing courses in the corresponding areas. Faculty and students were asked to evaluate the effectiveness of these additional sixteen new learning modules with web-based personality learning assessment surveys in addition to the demographic, and student profile surveys. Small sample sizes are still a concern in the learning personality style analysis, but we are working toward combining all data for a specific learning module (e.g. "Curved Beam Learning Module" administered with minor changes over four years to obtain larger sample sizes to analyze. We are hopeful that as larger more diverse engineering colleges and universities join us in this work; their larger student populations will support statistically significant analysis of diverse student learning styles and MBTI personality analysis for these twenty eight ALMs.

\section{Overview of the Assessment Methodology}

To analyze the effectiveness of the FE learning modules, a level of improved understanding is calculated by relating quiz scores (taken before and again after the ALM is used) to the learning styles and personality types, followed by the application of basic statistical analysis. The end goal is to accurately and comprehensively assess the quality of the learning modules and whether they are serving students across different demographics and other factors. These assessment goals were accomplished through three project assessment objectives:

1. Assessment Methodology. Develop and implement an iterative assessment system.

2. Statistical Measures. Determine improvement in student learning across distributions. 
3. Equitability Study. Gain insight into the effectiveness of the FE learning modules across various personality and learning styles.

This paper presents the student educational improvement percentages of our FE ALMs from both Phase 1 and Phase 2 NSF awards plus the recent assessment of student educational improvement gains across personality types and learning styles for our new Phase 2 NSF grant FE ALMs modules. The following section discusses the pedagogical foundations of the project, including the aforementioned Kolb Learning Cycle

\section{Background}

\section{Kolb Learning Cycle}

The pedagogical foundations for this project are based, in part, upon the Kolb Learning Cycle $e^{23-}$ 25,33. The Kolb model [Fig. 1 below] describes a cycle around which learning experiences progress. Studies have shown that if a learning experience encompasses all four of the quadrants of the Kolb Cycle, that the experience is superior to one that does not cover all four quadrants. Navigating the complete Kolb Learning Cycle improves student retention of the complex numerical procedure involved in FE analysis. During courses integrating FE learning modules, students are introduced to FE theory within their traditional lectures. Professors cover background of the FE method, fundamental mathematics of FE, the topology of the various finite elements, error analysis of FE results, and how to model engineering problems using this technique. Portions of Kolb's cycle are interlaced with hands-on activities that begin stating the proposed problem in a real-world manner. FE learning modules provide specific instructions on how to build the FE model of the engineering problem to increase student performance in the analysis for "Concrete Experience" on Kolb's Cycle. 


\section{Figure 1. Kolb Learning Cycle}

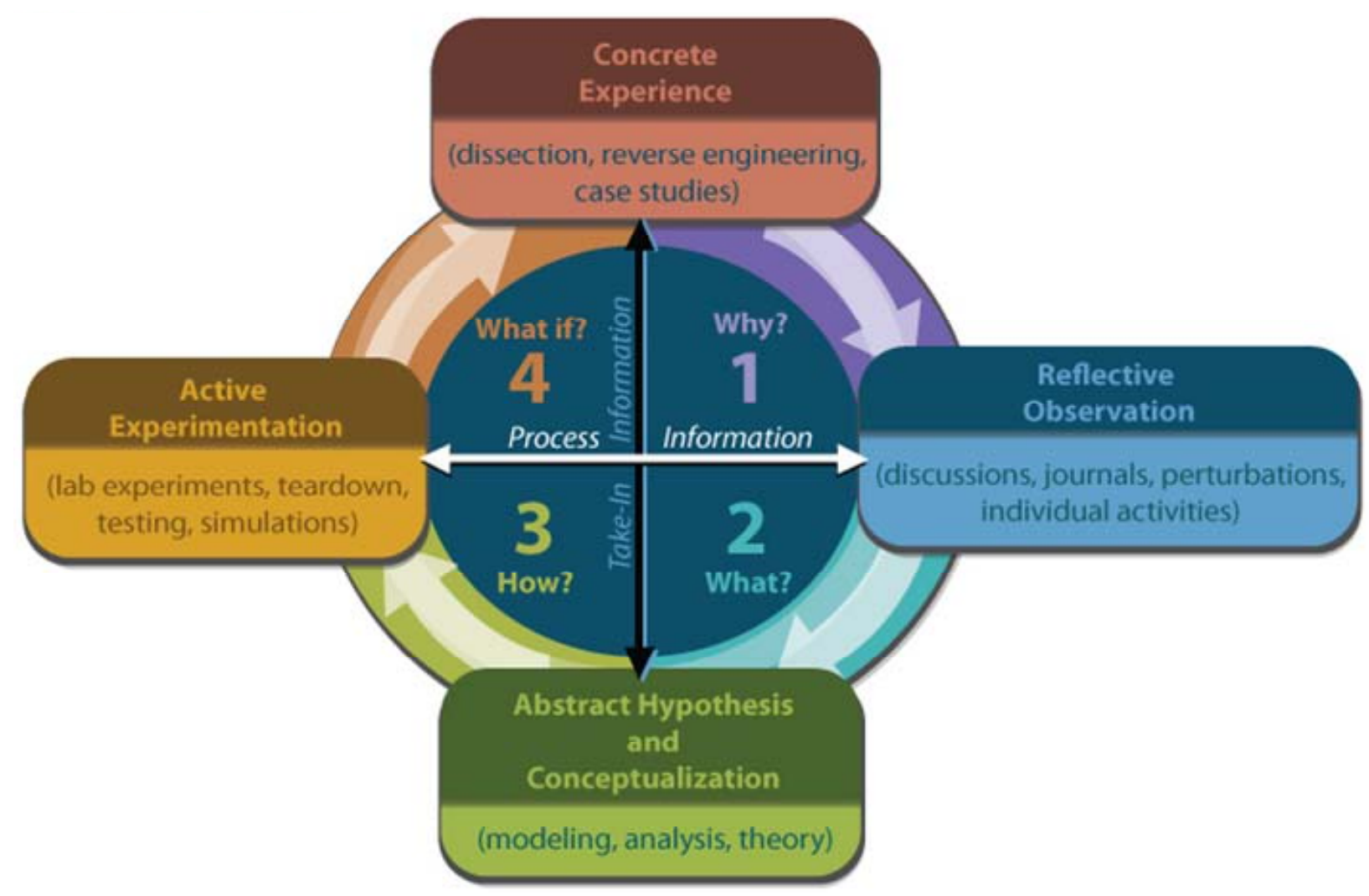

\section{Learning Styles}

Each FE ALM developed in this work is designed to span a spectrum of different characteristics in which students learn. The Felder-Soloman Index of Learning Styles ${ }^{25}$ is composed of four dimensions: active/reflective, sensing/intuitive, visual/verbal, and sequential/global [Table 1]. Active learning tools are designed to meet the needs of students with a range of learning styles. Particular approaches to teaching often favor a certain learning preference. Therefore it is important to incorporate a variety of teaching approaches This index can assist instructors in creating active learning modules that impact all student learning styles effectively. 


\section{Figure 2. Learning Styles Categories.}

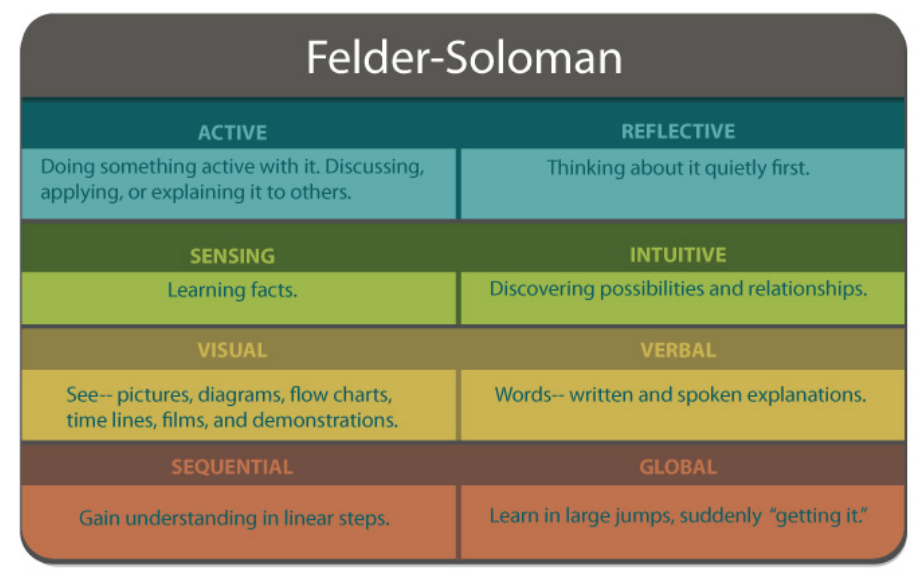

\section{Myers Briggs Type Indicator (MBTI) Personality Type}

The Myers Briggs Type Indicator (MBTI) is similar to the Felder-Silverman Learning Styles, but is linked to personality preferences [Figure 2]. MBTI includes four categories of how an individual processes and evaluates information ${ }^{29}$. The first category describes how a person interacts with his or her environment. People who take initiative and gain energy from interactions are known as Extroverts (E). Introverts (I), on the other hand prefer more of a relatively passive role and gain energy internally. The second category describes how a person processes information. A person who process data with their senses is referred to as a Sensors (S) and a person who sees where data is going in the future are called an iNtuitor $(\mathrm{N})$. The Sensor versus iNtuitor category is an interesting area of study when it comes to engineering education, because professors are historically intuitors while most engineering students are sensors ${ }^{49}$. The third category for MBTI preference describes the manner in which a person evaluates information. Those who tend to use a logical cause and effect strategy, Thinkers (T), differ from those who use a hierarchy based on values or the manner in which an idea is communicated, Feelers (F). The final category indicates how a person makes decisions or comes to conclusions. Perceivers $(\mathrm{P})$ prefer to be sure all the data is thoroughly considered, and Judgers (J) summarize the situation as it presently stands and make decisions more quickly.

A number of researchers have used knowledge of MBTI types to enhance engineering education $^{23,25,29 \text {, and } 31}$. In this prior educational research, it has been shown that different MBTI types respond in unique ways to distinctive pedagogical approaches. The goal of using the MBTI data in concurrence with learning modules is to ensure the FE tutorials are effective across different personality types, bringing any of these nuances to light. The innovative step to our analysis here is to take the assessment one step beyond effectiveness. We are looking into how equally this effectiveness reaches across demographic groups, learning styles, and personality. 


\section{Figure 3. Overview of Personality Preferences}

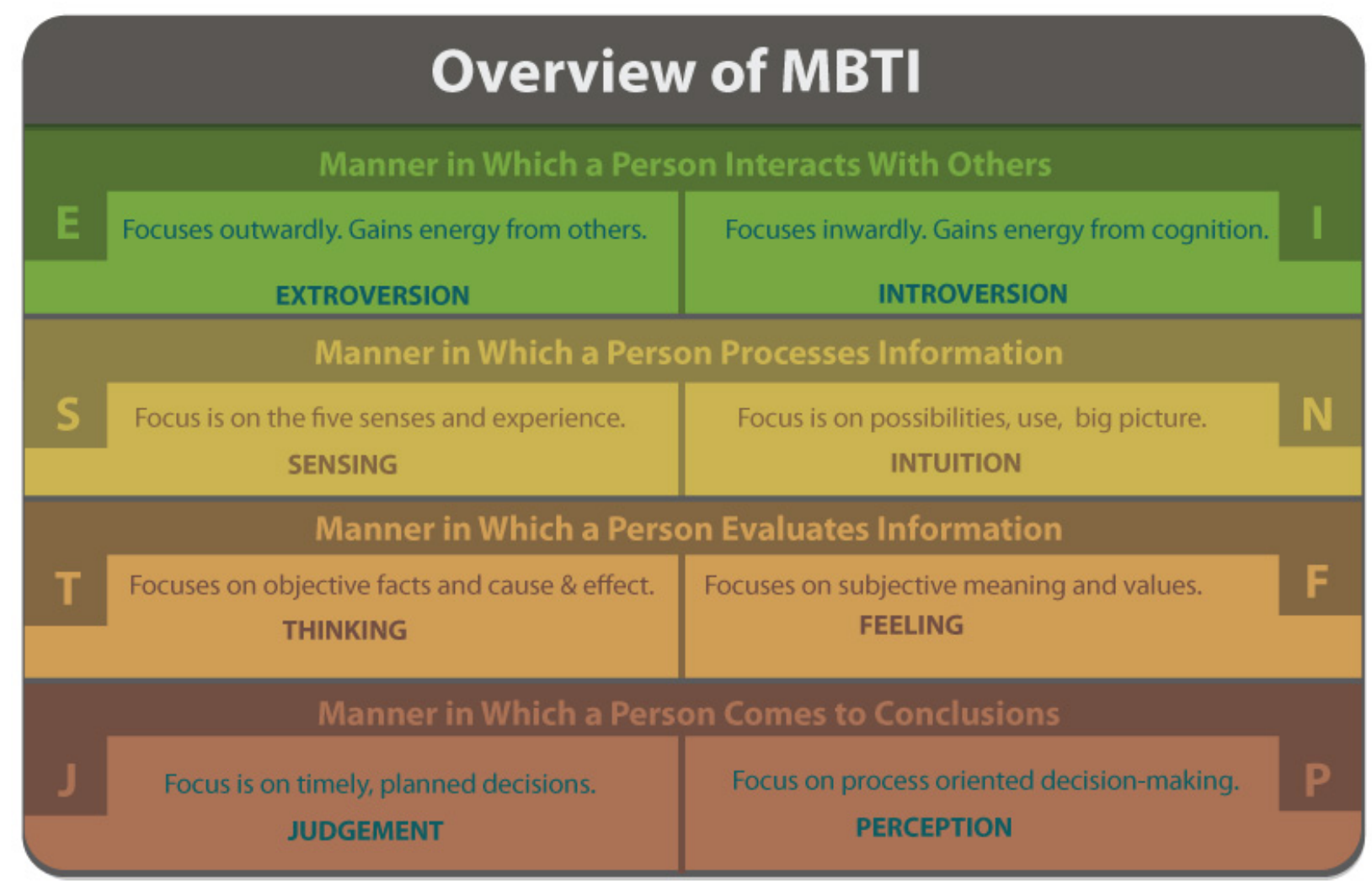

\section{Assessment Methodology}

\section{FE Active Learning Module (ALM)}

A starting point for our educational objectives is the development of the FE ALM. Each learning module is pedagogically rooted in an active learning style based on Kolb's Learning Cycle. By completing the cycle fully, the student will have a stronger grasp of the difficult engineering and FE material. As an accompaniment to traditional lectures, the learning module helps guide students through active experimentation, concrete experiences, and reflective observation. The FE ALMs are designed for those students who have little to no experience using the FE analysis. Therefore, the basic natures of the problems increase the possibility that the students will grasp the correlations between the physical solution and the computational model. Each module was developed in PowerPoint and is available in ppt and pdf file formats. Each FE ALM was developed with a common template presented as follows: 
- FE ALM Design Template.

- Table of contents.

- Project educational objectives based upon ABET Criteria 3 for Engineering Programs.

- Problem description.

- Problem analysis objectives.

- General steps and specific step-by-step analysis.

- Visualization of the results of the FE analysis.

- Comparison of FE analysis to another technique.

- Summary and discussion.

- Background information on finite element theory.

The FE ALMs are currently linked to one of six commercial FE codes (SolidWorks Simulation, SolidWorks Flow Simulation, MSC. Nastran, Comsol, ANSOFT, or AdvantEdge) all commonly used in industry.

\section{Assessment Foundations}

Helpful steps to assessments for the FE learning modules are: (a) gathering student demographics (i.e. academic major, educational level, grade point average, age, ethnicity, and gender); (b) gathering Felder-Soloman learning styles and MBTI personality type (this analysis, along with learning objectives, can be reviewed and fed back into improving the learning modules); and (c) collecting all data and linking these data to a common student identification number for future evaluations and survey responses.

The next step is developing a measurement instrument for evaluating student learning directly associated with the ALM. In this work, a multiple-choice quiz is used as the foundation for our baseline study. The content-based quiz is administered after the FE material is presented in class, but prior to the student being introduced to an FE learning module. This ideally isolates enhanced student learning due to the learning module alone. The learning modules supplement student learning of the difficult FE theories and methods, and associated engineering topic content. The same quiz is administered following the completion of the FE ALM. The pre-quiz and post-quiz scores are again linked to the common student ID. In parallel, as soon as the student completes the FE learning module, an in-depth survey is administered to the students, providing the opportunity for much more open feedback to the assessment system. 


\section{Summary of the Assessment Program Results to Date}

The assessment program can be divided into two distinct goals:

- Demonstrate learning improvement using the FE ALMs

- Develop an iterative assessment process that shows no bias towards learning styles and personality types using the FE ALMs

We first show that the Learning Improvement goal has been met for each of the Phase $1 \mathrm{FE}$ Learning Modules using quizzes administered prior to, and then again after students complete the learning modules. We have summarized the improved student learning for the Phase $1 \mathrm{FE}$ Learning Modules in Table $\mathbf{1}$ and Table $\mathbf{1 b}$ for ten of the original twelve learning modules used at the three engineering colleges These FE ALMs reported here are:

- Curved Beam Structural Learning Module

- Bolt and Plate Stiffness Learning Module

- Vibration Analysis of a Cantilever Beam

- Long Bar Steady State Heat Transfer

- L-Bracket Transient Heat Transfer

- Biomedical Electromagnetics

- Electromagnetics Specific Absorption Rates

- Electromagnetics Transmission Parameters of Infinitely Long Co-Axial Cable

- Electromagnetics Probe Feed of a Patch Antenna

- Computational Flow over a Cylinder

- Computational Flow with Friction in a Pipe 


\begin{tabular}{|c|c|c|c|c|c|}
\hline & Table 1 & Summary Table of P1 & hase I Improved Learnin & E Learning Modules & \\
\hline \multirow[t]{2}{*}{ FE Learning Module } & Semester/Institution & Number of Students & Pre-Quiz Average Score & Post-Quiz Average Score & Student Improvements Percentages \\
\hline & & & out of 100 points & out of 100 points & \\
\hline $\begin{array}{l}\text { Structual Analysis of a } \\
\text { Curved Beam }\end{array}$ & Fall 2006/ UOP & 9 & 71.1 & 82.2 & $15.60 \%$ \\
\hline Curved Beam & Fall 2007/UOP & 16 & 52.75 & 66.31 & $23.81 \%$ \\
\hline Curved Beam & Fall 2008/UOP & 10 & 61.1 & 74.6 & $22.09 \%$ \\
\hline Curved Beam & Fall 2009/UOP & 13 & 46.15 & 81.31 & $76.19 \%$ \\
\hline Curved Beam & Fall 2010/UOP & 15 & 63.33 & 75.5 & $19.22 \%$ \\
\hline \multicolumn{2}{|c|}{ Averages for Curved Beam } & 12.6 & 58.9 & 76.0 & $31.38 \%$ \\
\hline Bolt and Plate Stiffness & Snring 2007/UOP & 12 & 55.8 & 650 & $16.40 \%$ \\
\hline Bolt and Plate Stiffness & Spring $2010 / \mathrm{UOP}$ & 8 & 66.5 & 74.13 & $11.50 \%$ \\
\hline Averages for Stiffness & & 10 & & & \\
\hline Averages ior siminess & & 10 & 01.2 & 69.0 & $13.95 \%$ \\
\hline $\begin{array}{l}\text { Vibration Analysis of a } \\
\text { Cantilever Beam }\end{array}$ & Fall 2007/Tuskegee U. & 7 & 63.1 & 79.6 & $26.10 \%$ \\
\hline Cantilever Beam & Fall 2008/Tuskegee U. & 5 & 43.4 & 63.6 & $48.54 \%$ \\
\hline Cantilever Beam & Fall 2007/UOP & 16 & 52.8 & 65.3 & $23.70 \%$ \\
\hline Cantilever Beam & Fall 2008/UOP & 15 & 66 & 74 & $12.10 \%$ \\
\hline Averages for Vib Beam & & 10.8 & 56.3 & 70.6 & $27.61 \%$ \\
\hline $\begin{array}{l}\text { Long Bar Steady State } \\
\text { Heat Transfer }\end{array}$ & Spring 2007/UOP & 19 & 63.16 & 72.37 & $14.58 \%$ \\
\hline $\begin{array}{l}\text { L-Bracket Transient Heat } \\
\text { Transfer }\end{array}$ & Spring 2009/UOP & 14 & 69.86 & 78 & $11.65 \%$ \\
\hline Ave. for Heat Transfer & & 16.5 & 66.5 & 75.2 & $13.12 \%$ \\
\hline $\begin{array}{l}\text { Biomedical } \\
\text { Electromagnetics }\end{array}$ & Fall 2006/UOP & 6 & 50 & 76.7 & $53.34 \%$ \\
\hline Bio Electromagnetics & Fall 2007/UOP & 7 & 57.1 & 80 & $40.03 \%$ \\
\hline Bio Electromagnetics & Fall 2009/UOP & 7 & 36.73 & 59.16 & $61.12 \%$ \\
\hline Bio Electromagnetics & Fall 2010/UOP & 13 & 38.46 & 67.03 & $74.28 \%$ \\
\hline Ave. for Bio Electromag & & 8.3 & 45.6 & 70.7 & $\mathbf{5 7 . 1 9 \%}$ \\
\hline $\begin{array}{l}\text { Electromagnetics } \\
\text { Specific Absorption } \\
\text { Rates }\end{array}$ & Fall 2006/Gonzaga U. & 20 & 63.8 & 81.5 & $27.70 \%$ \\
\hline $\begin{array}{l}\text { Electromagnetics } \\
\text { Transmission Parameters } \\
\text { of Infinitely Long Co- } \\
\text { Axial Cable }\end{array}$ & Fall $2007 /$ Gonzaga U. & 10 & 42.5 & 67.5 & $58.80 \%$ \\
\hline $\begin{array}{l}\text { Electromagnetics Probe } \\
\text { Feed Patch Antenna }\end{array}$ & Spring 2008/Gonzaga U. & 10 & 60 & 81.3 & $35.50 \%$ \\
\hline Ave of Electromag & & 13.3 & 55.4 & 76.8 & $40.67 \%$ \\
\hline & & & & & \\
\hline
\end{tabular}




\begin{tabular}{|c|c|c|c|c|c|}
\hline & Table 1b & Summary Table of & Phase 1 Improved Learn & n FE Learning Modules & \\
\hline \multirow[t]{2}{*}{ FE Learning Module } & Semester /Institution & Number of Student & Pre-Quiz Average Score & Post-Quiz Average Score & Student Improvement Percentages \\
\hline & & & out of 100 points & out of 100 points & \\
\hline $\begin{array}{l}\text { Computational Flow over } \\
\text { a Cylinder }\end{array}$ & Fall 2007/Tuskegee U. & 7 & 49.9 & 77.1 & $54.50 \%$ \\
\hline $\begin{array}{l}\text { Computational Flow with } \\
\text { Friction in a Pipe }\end{array}$ & Fall 2007/Tuskegee U. & 7 & 58.0 & 77.1 & $32.93 \%$ \\
\hline \multicolumn{2}{|l|}{ Averages of CFD Modules } & 7 & 53.95 & 77.1 & $43.72 \%$ \\
\hline & & & & & \\
\hline & & & & & \\
\hline & & & & & \\
\hline & & & & & \\
\hline & & & & & \\
\hline
\end{tabular}

We next will show a Summary of Year 2 Student Improvement and Personality/Learning Style Results for Twelve (12) Phase 2 Learning Modules (2011-2012) during the second year of this National Science Foundation Grant. 


\section{Table 2 Summary of Year 2 and 3 Student Improvement and Personality Learning Style Results for Phase 2 Learning Modules (2011-2012)}

\begin{tabular}{|c|c|c|c|c|c|c|c|}
\hline FE Learning Module & Semester & Institution & $\begin{array}{l}\text { Students } \\
(\mathrm{N})\end{array}$ & $\begin{array}{l}\text { Pre-Quiz } \\
\text { Avg (\%) }\end{array}$ & $\begin{array}{l}\text { Post-Quiz } \\
\text { Avg (\%) }\end{array}$ & $\begin{array}{c}\% \text { Student } \\
\text { Improvement }^{1}\end{array}$ & $\begin{array}{l}\text { Subgroup differences } \\
\text { MBTI or ILS }\end{array}$ \\
\hline $\begin{array}{l}\text { Structural Analysis of Large } \\
\text { Deformation of a Cantilever } \\
\text { Beam }\end{array}$ & Fall 2011 & Tuskegee & 16 & 33.0 & 35.2 & $\begin{array}{c}6.90 \\
(p=0.523)\end{array}$ & $\begin{array}{c}\text { Introvert }(\mathrm{N}=7)>\text { Extrovert } \\
(\mathrm{N}=9)^{* *} \\
(\mathrm{MBTI} ; \mathrm{p}=0.034)\end{array}$ \\
\hline Axisymmetric Rocket Nozzle & Fall 2011 & USAFA & 11 & 42.0 & 54.5 & $\begin{array}{c}29.73 * \\
(\mathrm{p}=0.093)\end{array}$ & $\begin{array}{c}\text { Extrovert }(\mathrm{N}=5)>\text { Introvert } \\
(\mathrm{N}=5)^{* *} \\
(\mathrm{MBTI} ; \mathrm{p}=0.014)\end{array}$ \\
\hline Small Engine Cooling Fin & Fall 2011 & USAFA & 11 & 63.6 & 59.1 & $\begin{array}{c}-7.14 \\
(p=0.397)\end{array}$ & No \\
\hline $\begin{array}{l}\text { Vibration of Critical Speeds in } \\
\text { Rotating Shafts }\end{array}$ & Fall 2011 & Pomona & 9 & 62.2 & 72.2 & $\begin{array}{c}16.07^{*} \\
(\mathrm{p}=0.067)\end{array}$ & $\begin{array}{c}\text { Introvert }(\mathrm{N}=6)>\text { Extrovert } \\
(\mathrm{N}=3)^{* *} \\
(\mathrm{MBTI} ; \mathrm{p}=0.033)\end{array}$ \\
\hline $\begin{array}{l}\text { Computational Fluid Drag of } \\
\text { Bobsled Model }\end{array}$ & Fall 2011 & UoP & 17 & 50.0 & 65.3 & $\begin{array}{c}30.60 * * \\
(\mathrm{p}<0.001)\end{array}$ & No \\
\hline $\begin{array}{l}\text { Vibration of Critical Speeds in } \\
\text { Rotating Shafts }\end{array}$ & Fall 2011 & UoP & 25 & 47.2 & 59.2 & $\begin{array}{c}25.42 * * \\
(\mathrm{p}=0.003)\end{array}$ & $\begin{array}{c}\text { Intuitive }(\mathrm{N}=12)>\text { Sensing } \\
(\mathrm{N}=13)^{* *} \\
(\mathrm{MBTI} ; \mathrm{p}=0.018)\end{array}$ \\
\hline $\begin{array}{l}\text { Machining Analysis During Chip } \\
\text { Formation }\end{array}$ & $\begin{array}{l}\text { Spring } \\
2012\end{array}$ & UoP & 12 & 50.8 & 83.3 & $\begin{array}{c}64.18 * * \\
(\mathrm{p}<0.001)\end{array}$ & $\begin{array}{l}\text { Perception }(\mathrm{N}=2)> \\
\text { Judgment }(\mathrm{N}=10)^{* *} \\
(\mathrm{MBTI} ; \mathrm{p}=0.046)\end{array}$ \\
\hline $\begin{array}{l}\text { Thermal FEA: Semi Infinite } \\
\text { Medium and Steady-State Heat } \\
\text { Conduction }\end{array}$ & $\begin{array}{l}\text { Spring } \\
2012\end{array}$ & UoP & 26 & 62.5 & 74.7 & $\begin{array}{c}19.52 * * \\
(\mathrm{p}=0.002)\end{array}$ & No \\
\hline $\begin{array}{l}\text { Power Transmission Shaft Stress } \\
\text { Analysis }\end{array}$ & $\begin{array}{c}\text { Spring } \\
2012 \\
\end{array}$ & UoP & 17 & 59.3 & 81.4 & $\begin{array}{c}37.19 * * \\
(\mathrm{p}<0.001)\end{array}$ & $\mathrm{N} / \mathrm{A}$ \\
\hline $\begin{array}{l}\text { Defibrillation Electrode } \\
\text { Modeling }\end{array}$ & $\begin{array}{l}\text { Spring } \\
2012\end{array}$ & Washington & 18 & 27.1 & 57.6 & $\begin{array}{c}112.82 * * \\
(\mathrm{p}<0.001)\end{array}$ & No \\
\hline Bioelectric Field Modeling & $\begin{array}{l}\text { Spring } \\
2012\end{array}$ & Washington & 19 & 45.9 & 63.9 & $\begin{array}{c}39.34 * * \\
(\mathrm{p}<0.001)\end{array}$ & $\begin{array}{c}\text { Sequential }(\mathrm{N}=12)>\text { Global } \\
(\mathrm{N}=7)^{* *} \\
(\mathrm{ILS} ; \mathrm{p}=0.041)\end{array}$ \\
\hline $\begin{array}{l}\text { Sheet metal forming using FE } \\
\text { Analysis: Shallow Drawing of a } \\
\text { Circular Sheet }\end{array}$ & $\begin{array}{l}\text { Spring } \\
2012\end{array}$ & Tuskegee & 18 & 50.0 & 56.7 & $\begin{array}{c}13.33 * \\
(p=0.083)\end{array}$ & No \\
\hline Curved Beam Structural & Fall 2012 & UoP & 36 & 72.2 & 89.4 & $\begin{array}{c}23.72 * * \\
(p<0.001)\end{array}$ & No \\
\hline $\begin{array}{l}\text { Computational Fluid Drag of } \\
\text { Bobsled Model }\end{array}$ & Fall 2012 & UoP & 8 & 48.8 & 72.5 & $\begin{array}{c}48.72 * * \\
(p=0.001)\end{array}$ & No \\
\hline Axisymmetric Rocket Nozzle & Fall 2012 & USAFA & 16 & 42.2 & 67.2 & $\begin{array}{c}59.26^{* *} \\
(\mathrm{p}<0.001)\end{array}$ & No \\
\hline Small Engine Cooling Fin & Fall 2012 & USAFA & 16 & 39.1 & 59.4 & $\begin{array}{c}44.74 * * \\
(\mathrm{p}<0.001)\end{array}$ & No \\
\hline \multicolumn{6}{|c|}{ Overall Student Improvement Average } & $35.28 \%$ & \\
\hline
\end{tabular}

${ }^{1}$ Percent $(\%)$ Improvement $=[$ (post-quiz score - pre-quiz score $) /$ pre-quiz score $] * 100$

${ }^{2}$ Felder-Soloman Index of Learning Styles (ILS); Myers Brigg Type Indicator (MBTI)

** Sufficient evidence of statistically significant improvement $(\mathrm{p}<0.05)$

* Moderate evidence of statistically significant improvement $(0.05 \leq p<0.10)$ 
The next goal of this research is to show no bias towards learning styles and personality type. This goal is a bit more difficult to achieve at the nine engineering colleges as the FE ALMs are administered to upper level junior and senior level classes with small enrollments. We have been successful in combining the small student populations for the original FE Learning Modules administered in the early years of this research without modifications. These combined results are providing preliminary information on those student learning styles and personality types that are improving their learning more than their colleagues.

\section{Assessment results for the first and second goal of this research}

We administered twelve of the Phase 2 FE ALMs during the second year of this research and focused on measuring both student learning content using the pre and post learning module quizzes and student learning bias toward a specific Myers Brigg Type Indicator (MBTI) or Index of Learning Style (ILS) as measured with the on-line MBTI survey and the on-line FelderSolomon survey. Six of the learning modules suggested no bias toward a specific MBTI or Index of Learning Style and six of the learning modules suggested a bias toward a specific MBTI or Index of Learning Style.

The twelve FE Learning Modules analyzed during the Second Year of this research were

- Structural Analysis of Large Deformation of a Cantilever Beam

- Sheet Metal Forming using FE Analysis: Shallow Drawing of a Circular Sheet

- Vibration of Critical Speeds of Rotating Shafts

- Computational Fluid Drag of a Bobsled Model

- Power Transmission Shaft Stress Analysis

- Machining Analysis during Chip Formation

- Thermal Finite Element Analysis: Semi-Infinite Medium

- Thermal Finite Element Analysis: Steady Heat Conduction

- Axisymmetric Rocket Nozzle

- Small Engine Cooling Fin

- Defibrillation Electrode Modeling

- Bioelectric Field Modeling 


\section{Results for student improvement using these twelve FE ALMs}

The average improvement for the twelve learning modules administered was $32.33 \%$ where the number of students tested is shown as $\mathrm{N}$, the quiz scores (both pre and post) are out of $100 \%$, and the \% Student Improvement for each of these twelve modules is shown above in this table 2. Three of the twelve FE learning modules showed moderate evidence of improved student performance with statistical values of $p<0.10$ as noted in this table by **. Seven of the twelve FE learning modules showed sufficient evidence of improved student performance with statistical values of $p<0.05$. Two of the twelve FE ALMs showed insufficient evidence of improved student performance (i.e. $p=0.523$ and $p=0.397$ ). The authors of these two FE learning modules will be working this academic year to improve their FE learning modules, assessment quizzes and other instruments to improve their students' performance.

These results are shown below in table 3 as the interpretation of Results learning module for Phase II Learning Modules (2011-2012)

\section{Table 3 Interpretation of Results by Active Learning Module for Phase 2 Learning Modules (2011-2012)}

\begin{tabular}{|c|c|c|c|c|}
\hline FE Learning Module & Semester & Institution & Student Improvement & Subgroup differences MBTI or ILS \\
\hline $\begin{array}{l}\text { Structural Analysis } \\
\text { of Large } \\
\text { Deformation of a } \\
\text { Cantilever Beam }\end{array}$ & $\begin{array}{c}\text { Fall } \\
2011\end{array}$ & Tuskegee & $\begin{array}{l}\text { There is insufficient evidence to } \\
\text { suggest that performance on the } \\
\text { Cantilever Beam quiz will } \\
\text { increase after students complete } \\
\text { the module. }\end{array}$ & $\begin{array}{l}\text { A statistically significant subgroup difference was } \\
\text { found between those typed as "introvert" versus } \\
\text { "extrovert" using the MBTI, where greater gains were } \\
\text { made by the "introvert" subgroup, on average ( } \mathrm{p}= \\
0.034 \text { ). } \\
\text { This category on the MBTI looks at the manner with } \\
\text { which a person interacts with others. Extroverts tend to } \\
\text { take initiative and gain energy from interactions, } \\
\text { whereas introverts prefer more of a relatively passive } \\
\text { role and gain energy internally (from cognition). }\end{array}$ \\
\hline $\begin{array}{l}\text { Axisymmetric } \\
\text { Rocket Nozzle }\end{array}$ & $\begin{array}{c}\text { Fall } \\
2011\end{array}$ & USAFA & $\begin{array}{l}\text { There is MODERATE evidence } \\
\text { to suggest that performance on } \\
\text { the Rocket Nozzle quiz will } \\
\text { increase after students complete } \\
\text { the module }(\mathrm{p}=0.093) \text {. }\end{array}$ & $\begin{array}{l}\text { A statistically significant subgroup difference was } \\
\text { found between those typed as "introverted" versus } \\
\text { "extroverted" using the MBTI, where greater gains } \\
\text { were made by the "extrovert" subgroup, on average (p } \\
=0.014 \text { ). } \\
\text { An "introvert" personality type tends to focus inwardly } \\
\text { and gain energy from cognition, whereas an } \\
\text { "extrovert" personality type tends to focus outwardly } \\
\text { and gain energy from others. }\end{array}$ \\
\hline $\begin{array}{l}\text { Small Engine } \\
\text { Cooling Fin }\end{array}$ & $\begin{array}{c}\text { Fall } \\
2011\end{array}$ & USAFA & $\begin{array}{l}\text { There is insufficient evidence to } \\
\text { suggest that performance on the } \\
\text { Cooling Fin quiz will increase } \\
\text { after students complete the } \\
\text { module. }\end{array}$ & $\begin{array}{l}\text { No evidence of subgroup differences was found based } \\
\text { on MBTI and ILS performance. Therefore no } \\
\text { subgroup of students had an advantage over other } \\
\text { subgroups of students. }\end{array}$ \\
\hline $\begin{array}{l}\text { Vibration of } \\
\text { Critical Speeds in }\end{array}$ & $\begin{array}{c}\text { Fall } \\
2011\end{array}$ & Pomona & $\begin{array}{l}\text { There is MODERATE evidence } \\
\text { to suggest that performance on }\end{array}$ & $\begin{array}{l}\text { A statistically significant subgroup difference was } \\
\text { found between those typed as "introvert" versus }\end{array}$ \\
\hline
\end{tabular}




\begin{tabular}{|c|c|c|c|c|}
\hline Rotating Shafts & & & $\begin{array}{l}\text { the Rotating Shafts quiz will } \\
\text { increase after students complete } \\
\text { the module }(\mathrm{p}=0.067)\end{array}$ & $\begin{array}{l}\text { "extrovert" using the MBTI, where greater gains were } \\
\text { made by the "introvert" subgroup, on average ( } \mathrm{p}= \\
0.033 \text { ). } \\
\text { This category on the MBTI looks at the manner with } \\
\text { which a person interacts with others. Extroverts tend to } \\
\text { take initiative and gain energy from interactions, } \\
\text { whereas introverts prefer more of a relatively passive } \\
\text { role and gain energy internally (from cognition). }\end{array}$ \\
\hline $\begin{array}{l}\text { Computational } \\
\text { Fluid Drag of } \\
\text { Bobsled Model }\end{array}$ & $\begin{array}{l}\text { Fall } \\
2011\end{array}$ & UoP & $\begin{array}{l}\text { There is evidence to suggest that } \\
\text { performance on the Bobsled quiz } \\
\text { will increase after students } \\
\text { complete the module }(\mathrm{p}<0.001)\end{array}$ & $\begin{array}{l}\text { No evidence of subgroup differences was found based } \\
\text { on MBTI and ILS performance. Therefore no } \\
\text { subgroup of students had an advantage over other } \\
\text { subgroups of students. }\end{array}$ \\
\hline $\begin{array}{l}\text { Vibration of } \\
\text { Critical Speeds in } \\
\text { Rotating Shafts }\end{array}$ & $\begin{array}{c}\text { Fall } \\
2011\end{array}$ & UoP & $\begin{array}{l}\text { There is evidence to suggest that } \\
\text { performance on the Rotating } \\
\text { Shafts quiz will increase after } \\
\text { students complete the module (p } \\
=0.003 \text { ) }\end{array}$ & $\begin{array}{l}\text { A statistically significant subgroup difference was } \\
\text { found between those typed as "intuitive" versus } \\
\text { "sensing" using the MBTI, where greater gains were } \\
\text { made by the "intuitive" subgroup, on average ( } \mathrm{p}= \\
\text { 0.018). } \\
\text { This category on the MBTI looks at the manner with } \\
\text { which a person process information. Sensors tend to } \\
\text { process information with their focus on their five } \\
\text { senses and the environment, whereas intuitors tends to } \\
\text { focus on the possibilities of the information and see the } \\
\text { big picture. Engineering students tend to be sensors, } \\
\text { while professors tend to be intuitors. }\end{array}$ \\
\hline $\begin{array}{l}\text { Power Transmission } \\
\text { Shaft Stress } \\
\text { Analysis }\end{array}$ & $\begin{array}{c}\text { Spring } \\
2012\end{array}$ & UoP & $\begin{array}{l}\text { There is evidence to suggest that } \\
\text { performance on the Shaft Stress } \\
\text { quiz will increase after students } \\
\text { complete the module }(\mathrm{p}<0.001) \text {. }\end{array}$ & MBTI and ILS data were not collected for this module. \\
\hline $\begin{array}{l}\text { Machining Analysis } \\
\text { During Chip } \\
\text { Formation }\end{array}$ & $\begin{array}{c}\text { Spring } \\
2012\end{array}$ & UoP & $\begin{array}{l}\text { There is evidence to suggest that } \\
\text { performance on the Chip } \\
\text { Formation quiz will increase } \\
\text { after students complete the } \\
\text { module }(\mathrm{p}<0.001)\end{array}$ & $\begin{array}{l}\text { A statistically significant subgroup difference was } \\
\text { found between those typed as "perceivers" versus } \\
\text { "judgers" using the MBTI, where greater gains were } \\
\text { made by the "perception" subgroup, on average (p = } \\
0.046 \text { ). } \\
\text { This category on the MBTI looks at the manner in } \\
\text { which a person comes to conclusions. Perceivers } \\
\text { prefer to be sure all data are thoroughly considered, } \\
\text { whereas judgers summarize the situation as it presently } \\
\text { stands and make decisions more quickly. }\end{array}$ \\
\hline $\begin{array}{l}\text { Thermal FEA: Semi } \\
\text { Infinite Medium } \\
\text { and Steady-State } \\
\text { Heat Conduction }\end{array}$ & $\begin{array}{c}\text { Spring } \\
2012\end{array}$ & UoP & $\begin{array}{l}\text { There is evidence to suggest that } \\
\text { performance on the Thermal } \\
\text { FEA quiz will increase after } \\
\text { students complete the modules (p } \\
=0.002 \text { ) }\end{array}$ & $\begin{array}{l}\text { No evidence of subgroup differences was found based } \\
\text { on MBTI and ILS performance. Therefore no } \\
\text { subgroup of students had an advantage over other } \\
\text { subgroups of students. }\end{array}$ \\
\hline $\begin{array}{l}\text { Defibrillation } \\
\text { Electrode Modeling }\end{array}$ & $\begin{array}{c}\text { Spring } \\
2012\end{array}$ & Washington & $\begin{array}{l}\text { There is evidence to suggest that } \\
\text { performance on the Defibrillation } \\
\text { quiz will increase after students } \\
\text { complete the module }(\mathrm{p}<0.001) \text {. }\end{array}$ & $\begin{array}{l}\text { No evidence of subgroup differences was found based } \\
\text { on MBTI and ILS performance. Therefore no } \\
\text { subgroup of students had an advantage over other } \\
\text { subgroups of students. }\end{array}$ \\
\hline $\begin{array}{l}\text { Bioelectric Field } \\
\text { Modeling }\end{array}$ & $\begin{array}{c}\text { Spring } \\
2012\end{array}$ & Washington & $\begin{array}{l}\text { There is evidence to suggest that } \\
\text { performance on the Bioelectric } \\
\text { quiz will increase after students } \\
\text { complete the module }(\mathrm{p}<0.001)\end{array}$ & $\begin{array}{l}\text { A statistically significant subgroup difference was } \\
\text { found between those typed as "sequential" versus } \\
\text { "global" using the ILS, where greater gains were made } \\
\text { by the "sequential" subgroup, on average }(\mathrm{p}=0.041) \text {. } \\
\text { A "sequential" learner tends to gain understanding in } \\
\text { linear steps, whereas a "global" learner tends to learn } \\
\text { in large jumps, suddenly "getting it". }\end{array}$ \\
\hline $\begin{array}{l}\text { Sheet metal forming } \\
\text { using FE Analysis: }\end{array}$ & $\begin{array}{l}\text { Spring } \\
2012\end{array}$ & Tuskegee & $\begin{array}{l}\text { There is MODERATE evidence } \\
\text { to suggest that performance on }\end{array}$ & $\begin{array}{l}\text { No evidence of subgroup differences was found based } \\
\text { on MBTI and ILS performance. Therefore no }\end{array}$ \\
\hline
\end{tabular}




\begin{tabular}{|c|c|c|c|c|}
\hline $\begin{array}{l}\text { Shallow Drawing of } \\
\text { a Circular Sheet }\end{array}$ & & & $\begin{array}{l}\text { the Shallow Drawing quiz will } \\
\text { increase after students complete } \\
\text { the module }(\mathrm{p}=0.083)\end{array}$ & $\begin{array}{l}\text { subgroup of students had an advantage over other } \\
\text { subgroups of students. }\end{array}$ \\
\hline $\begin{array}{l}\text { Curved Beam } \\
\text { Structural }\end{array}$ & $\begin{array}{c}\text { Fall } \\
2012\end{array}$ & $\mathrm{UoP}$ & $\begin{array}{l}\text { There is evidence to suggest that } \\
\text { performance on the Curved } \\
\text { Beam quiz will increase after } \\
\text { students complete the module (p } \\
<0.001 \text { ) }\end{array}$ & $\begin{array}{l}\text { No evidence of subgroup differences was found based } \\
\text { on MBTI and ILS performance. Therefore no } \\
\text { subgroup of students had an advantage over other } \\
\text { subgroups of students. }\end{array}$ \\
\hline $\begin{array}{l}\text { Computational } \\
\text { Fluid Drag of } \\
\text { Bobsled Model }\end{array}$ & $\begin{array}{c}\text { Fall } \\
2012\end{array}$ & UoP & $\begin{array}{l}\text { There is evidence to suggest that } \\
\text { performance on the Bobsled quiz } \\
\text { will increase after students } \\
\text { complete the module }(\mathrm{p}<0.001)\end{array}$ & $\begin{array}{l}\text { No evidence of subgroup differences was found based } \\
\text { on MBTI and ILS performance. Therefore no } \\
\text { subgroup of students had an advantage over other } \\
\text { subgroups of students. } \\
\text { However, it is important to note that not only was this } \\
\text { sample size small, but it was very homogeneous (i.e., } \\
\text { the majority of the participants fell in the same } \\
\text { subgroup in each pairing). }\end{array}$ \\
\hline $\begin{array}{l}\text { Axisymmetric } \\
\text { Rocket Nozzle }\end{array}$ & $\begin{array}{c}\text { Fall } \\
2012\end{array}$ & USAFA & $\begin{array}{l}\text { There is evidence to suggest that } \\
\text { performance on the Rocket } \\
\text { Nozzle quiz will increase after } \\
\text { students complete the module (p } \\
<0.001)\end{array}$ & $\begin{array}{l}\text { No evidence of subgroup differences was found based } \\
\text { on MBTI and ILS performance. Therefore no } \\
\text { subgroup of students had an advantage over other } \\
\text { subgroups of students. }\end{array}$ \\
\hline $\begin{array}{l}\text { Small Engine } \\
\text { Cooling Fin }\end{array}$ & $\begin{array}{c}\text { Fall } \\
2012\end{array}$ & USAFA & $\begin{array}{l}\text { There is evidence to suggest that } \\
\text { performance on the Cooling Fin } \\
\text { quiz will increase after students } \\
\text { complete the module }(\mathrm{p}<0.001) \text {. }\end{array}$ & $\begin{array}{l}\text { No evidence of subgroup differences was found based } \\
\text { on MBTI and ILS performance. Therefore no } \\
\text { subgroup of students had an advantage over other } \\
\text { subgroups of students. }\end{array}$ \\
\hline
\end{tabular}

\section{Results of Subgroup differences MBTI and ILS}

Table 3 above also includes the results of analysis of subgroup differences for the MBTI and ILS of student responses. Six of the FE learning modules showed no evidence of subgroup difference upon analysis of the MBTI and ILS surveys taken by the students, therefore these four modules were considered ideal in their handling of the student subgroups taking the quizzes. The student MBTI and ILS student survey data was misplaced for one (1) of the FE learning modules so it was not analyzed. Six of the FE learning modules show statistically significant subgroup differences $(p<0.05)$ for the MBTI and ILS student survey data.

\section{Results of the Subgroup Differences in MBIT and ILS data for the FE learning modules}

The following six FE ALMs were found to be ideal or showed statistically insignificant differences between the sixteen subgroups of students in the MBTI and ILS groups.

- Sheet metal forming using FE Analysis: Shallow Drawing of a Circular Sheet

- Computational Fluid Drag of a Bobsled Model

- Small Engine Cooling Fin-

- Defibrillation Electrode Modeling- 
- Thermal FEA Semi Infinite Heat Transfer

- Thermal FEA Steady State Heat Conduction

The following six(6) FE ALMs showed significant differences based upon MBTI and ILS types

Structural Analysis of Large Deformation of a Cantilever Beam Module

- A statistically significant subgroup difference was found between those students typed as "introvert" versus "extrovert" using the MBTI, where greater gains were made by the "introvert" subgroup on average $(\mathrm{p}=0.034)$.

Vibration of Critical Speeds in Rotating Shafts

- A statistically significant subgroup difference was found between those typed as “ introvert" versus "extrovert" using the MBTI, were greater gains were made by the "introvert" subgroup, on average $(\mathrm{p}=0.033)$.

Vibration of Critical Speeds in Rotating Shafts

- A statistically significant subgroup difference was found between those typed as "intuitive" versus "sensing" using the MBTI, where greater gains were made by the "intuitive" subgroup, on average $(\mathrm{p}=0.018)$.

Machining Analysis during Chip Formation

- A statistically significant subgroup difference was found between those typed as "perceivers" versus "judgers" using MBTI, where greater gains were made by the "perception" subgroup, on average ( $\mathrm{p}=0.046)$.

Axisymmetric Rocket Nozzle

- A statistically significant subgroup differences was found between those typed as "introverted" versus "extroverted" using the MBTI, where greater gains were made by the "extrovert" subgroup, on average $(\mathrm{p}=0.041)$. 
Bioelectric Field Modeling

- A statistically significant subgroup difference was found between those typed as "sequential" versus "global" using the ILS, where greater gains were made by the " sequential" subgroup, on average $(\mathrm{p}=0.041)$.

As part of our iterative assessment and improvement process, after we identified groups (either MBTI or ILS) that did not perform as well as their counterparts, we recommend adjustments in the ALM that can be implemented before the next time the ALM is used. The goal here is to reduce the difference in performance between the different MBTI or ILS groups, thus making the ALM learning enhancement equitable across MBTI and ILS types.

\section{Recommendations to remediate Differences in MBTI Data for the FE ALMs \\ *Sufficient evidence of statistically significant improvement $(\mathbf{p}<0.05)$}

\section{FE Learning Module with Differences}

$\underline{\text { Introverts }(\mathrm{N}=7)>\text { Extroverts }(\mathrm{N}=9)^{*}}$

- Insert more activities into the Active Learning Module to assist the extroverts

-Specifically, insert a collaborative learning experience into the procedure for implementation of the Active Learning Module.

\section{Extroverts $(\mathrm{N}=5)>$ Introverts $(\mathrm{N}=5)^{*}$}

-Insert periodic questions within the module to develop ideas internally

Add more word descriptions for developing the Active Learning Module and its solutions -If there is mandatory group work, consider making it the student(s) choice to do the work individually or in the group.

- Create a thought provoking, individually answered extra credit question inserting in the beginning of the Active Learning Module.

Recommendations to remediate Differences in MBTI and ILS Data for the FE ALMs

*Sufficient evidence of statistically significant improvement $(\mathbf{p}<0.05)$

\section{FE Learning Modules with Differences}


Sequential $(\mathrm{N}=12)>\operatorname{Global}(\mathrm{N}=7)^{*}$

-Increase the number of times each student can take the quiz after the Active Learning Module

-Provide a "read ahead" document ( 1 or 2 pages) that summarizes the content of the Active Learning Module and provides background to the students

\section{Conclusions}

This paper summarizes the work of two groups of researchers in gathering pre-post quiz data over the past six years using twenty eight learning modules in eight engineering areas. The Phase 1 work with the original twelve learning modules has provided evidence that student knowledge improvements ranged from $15 \%$ to $57 \%$ using pre- and post quizzes of student knowledge. As can be seen in Table 1 this measured improvement in student knowledge has been repeated over the past six years at three engineering institutions. This work has continued with the current Phase 2 work with twelve new learning modules From Table 2 we see sustained student improvement in knowledge in ten of the twelve modules averaging 32.33\% (using the same pre-post quiz methods). Our survey data analysis assists us in improving the performance of these learning modules and has shown positive student support for the work in the current learning modules and the past twelve learning modules.

We have embarked upon assessing the statistical differences in student responses to our Active Learning Modules by subgroups of the Myers Brigg Type Indicator (MBTI) and the FelderSolomon Index of Learning Styles (ILS) to improve the effectiveness of our modules in addressing differences( in learning styles and MBTI types) of our engineering students. We have determined that four (4) of our ALM's showed no significant differences in the sixteen subgroups of MBTI and ILS groups. Six of our ALM's did show significant differences in the subgroups of the MBTI and ILS groups and efforts are underway to enhance the effectiveness of these ALM's, for the specific ILS or MBTI types indicated, during the third year of the research.

\section{Future Efforts}

Our current twelve researchers analyzed the MBTI and ILS data gathered from over 1,000 students participating in this work at nine engineering institutions. The MBTI and ILS data is correlated with the pre and post quiz scores to determine if any MBTI or ILS types perform significantly better than their counterpart MBTI or ILS types. In cases where they do perform 
significantly better, we offer the ALM's author suggestions on how to refine the ALM (either in content or implementation process) in order to attempt to erase the differences in performance across MBTI or ILS types. The final step in this process will be to reassess the altered ALMs to determine if the differences in performance across MBTI or ILS types has been mitigated.

\section{Acknowledgements}

This work is partially supported by the National Science Foundation, Undergraduate Education Division with two four-year awards in the program of Transforming Undergraduate Education in Science Technology, Engineering and Mathematics (TUES) Phase 2 : Award Numbers 1023034 and 1023064 . We also acknowledge receiving support from the University of Texas at Austin Cockrell School of Engineering and the Cullen Trust Endowed Professorship in Engineering No. 1 and the support of the Department of Engineering Mechanics at the U.S. Air Force Academy as well as the financial support of the Dean's Assessment Funding Program.

\section{Bibliography}

1. Linsey, J., Talley, A., White, C., Jensen, D., and Wood, K., "From Tootsie Rolls to Broken Bones: An innovative Approach for Active Learning in Mechanics of Materials," Advances in Engineering Education, Vol. 1, No. 3, Winter 2009.

2. Thilmany, J., "FEA in a Snap," Mechanical Engineering, pp. 60-62, July 2001.

3. Mahoney, D.P., "Go with the Flow," Computer Graphics World, pp. 30-36, March 3, 1999.

4. Thilmany, J., "Analyzing up Front," Mechanical Engineering, Vol. 122, No.10, pp. 88-91.

5. Rencis, J.J., Flory, E., and Kwok, P., "Learning Modules for Finite Element Method on the World-Wide Web," Computers in Education Journal, Vol. 9, No. 4, pp. 22-28, 1999.

6. Brinson, L.C., Belytschko, T., Moran, B., and Black, T.,"Design and Computational Methods in Basic Mechanics Courses," Journal of Engineering Education, Vol. 86, No. 2, pp. 159166, 1997.

7. Graham, L., and Khan, M., "Use of ANSYS and MATLAB in an Introductory Finite Element Course," ASEE Computers in Education Journal, Vol. 12, No. 1, pp. 32-37, 2002.

8. Chiou, R., Ridenour, S., Lehman, G., Nguyen, T., and Thoonkuzhy, J., "Finite Element Analysis for Design of a Rail Lifter Train," AEEE Computers in Education Journal, Vol. 8, No. 4, pp. 50-55, 1998. 
9. Matthew, J., and Jahania, S., "Computer Applications for Interdepartmental Engineering Students through Finite Element Method," ASEE Computers in Education Journal, Vol. IX, No. 4, pp. 46-48, 1999.

10. Milton-Benoit, J., Grosse, I.R., Poli, C., and Woolf, B.P., "The Multimedia Finite Element Modeling and Analysis Tutor," Journal of Engineering Education, Vol. 97, No. 5, pp. 511$517,1998$.

11. Brown, A.O., "Undergraduate Finite Element Instruction using Commercial Finite Element Software Tutorials and Kolb Learning Cycle," Presented at the 2004 ASME International Mechanical Engineering Congress and Exposition, Anaheim, CA, November 18, 2004.

12. Brown, A.O., Rencis, J.J., Jensen, D.A., Chen, C.C., Ibrahim, E., Labay, V., and Schimpf, P., "Finite Element Learning Modules for Undergraduate Engineering Topics using Commercial Software," The 2008 ASEE Annual Conference \& Exposition, Pittsburgh, PA, June 22-25, 2008.

13. Liu, J., and Brown, A.O., "Enhancing Machine Design and Analysis Courses through the Introducing Design and FE Analysis Projects," Presented at the 2008 ASEE Pacific

Southwest Regional Conference, Northern Arizona University, Flagstaff, AZ, March 27-28, 2008.

14. Coffman, J., Liu, J., Brown, A.O., Terdalkar, S., and Rencis, J.J., "Finite Element Learning Modules for Improving Knowledge of Fatigue using Commercial Software," Proceedings of the 2009 ASEE Middle Atlantic Section Spring Meeting, Loyola College in Maryland, MD, April 24-25, 2009.

15. Kaufman, K., Brown, A.O., Wood, Jensen, D.A., and Rencis, J.J., "A Novel Assessment Methodology for Active Learning Modules to Equitably Enhance Engineering Education," Proceedings of the ASEE Annual Conference \& Exposition, Austin TX, June 14-17, 2009.

16. Kaufman, K., Wood, K.L., Singh, V., White, C., Jensen, D.A., Brown, A.O., Rencis, J.J., and Coffman, J., "Online Finite Element Learning Modules as Active Learning Tools, " Submitted to Advances in Engineering Education, November 2011.

17. Kaufman, K., Wood, K.L., Jensen, D.A., Brown, A.O., Rencis, J.J., and White, C., "A Novel Assessment Methodology for Active Learning Modules to Equitably Enhance Engineering Education," Submitted to International Journal of Engineering Education, October 2011.

18. Watson, K.A., and Brown, A.O., "Finite Element Analysis Tutorials for Undergraduate Heat Transfer Course," Proceedings of the 2009 ASEE Pacific Southwest Conference, National University, San Diego, CA, March 19-20, 2009. 
19. Watson, K.A., Brown, A.O., Hackett, R., and Pham A., Finite Element Analysis Learning Modules for an Undergraduate Heat Transfer Course: Implementation and Assessment, ASEE Annual Conference \& Exposition, San Antonio, TX, June 10-13, 2012 (Under Review).

20. Belytschko, T., Bayliss, A., Brinson, C., Carr, S., Kath, W., Krishnaswarmy, S., Moran, B, and Peshkin, M., "Mechanics in the Engineering First Curriculum at Northwestern University," International Journal for Engineering Education, Vol. 13, No. 6, pp. 457-472, 1997.

21. "Criteria for Accrediting Engineering Programs," Effective for Evaluations During the 20122013 Accreditation Cycle, ABET, Inc., Baltimore, MD, http://www.abet.org.

22. Nesbit, S.N., Comer, J.J., and Van Gulick, L.A., "Finite Element Method in Undergraduate Engineering

Education," Computer Applications in Engineering Education, Vol. 87, No. 5, pp. 511517, 1998.

23. Baker, J.R., Capece, V.R., and Lee, R.J., "Integration of Finite Element Software in Undergraduate Engineering

Courses," ASEE Computers in Education Journal, Vol. 12, No. 2, pp. 10-19, 2002.

24. Sorby, S.A., Walker, G., Yano, M., Glozman, V., Kochersberger, K., Mathers, J., McKinney, J. Schulman, J. and Young, M., "Modernization of the Mechanical Engineering Curriculum and Guidelines for Computer Aided Engineering Instruction," Computer Applications in Engineering Education, Vol. 7, No. 4, pp. 252-260, 1999.

25. Felder, R.M., and Silverman, L.K., "Learning and Teaching Styles in Engineering Education," Engineering Education, Vol. 78, No. 7, pp. 674-681, 1988.

26. Stice, J.E., "Using Kolb's Learning Cycle to Improve Student Learning," Engineering Education, pp. 291-296, February 1987.

27. Brown, A.O., "Teaching Finite Elements using the Kolb Learning Cycle," Presented at the ASEE Pacific Southwest Section Conference, University of the Pacific, Stockton, CA, April $1-2,2004$.

28. Kolb, D. A., Experimental Learning: Experience as the Source of Learning and Development, Prentice Hall, Englewood Cliffs, N.J., 1984.

29. Myers, I.B., and McCaulley, M.H., Manual: A Guide to the Development and Use of the Myer-Briggs Type Indicator, Consulting Psychologists Press, Palo Alto, CA, 1985. 
30. Borchert, R., Jensen, D.A., and Yates, D., "Hands-on and Visualization Modules for Enhancement of Learning

In Mechanics: Development and Assessment in the Context of Myers Briggs, Types and VARK Learning Styles," Proceedings of ASEE Annual Conference \& Exposition, Charlotte, NC, June 20-23, 1999.

31. Bower, M., Jensen, D.A., Feland, J., and Self, B., "When Multimedia Doesn't Work: An Assessment of Visualization Modules for Learning Enhancements in Mechanics," Proceedings of ASEE Annual Conference \& Exposition, St. Louis, MO, June 18-21, 2000. 